\title{
Does the WTO Accession Stimulate Inward FDI in Developing Countries? Accentuate on TRIMS, TRIPS or Trade Liberalization
}

\author{
Md. Shakib Hossain \\ Senior Lecturer, Department of Business Administration, East West University, Bangladesh \\ E-mail: sshakibhossain121@ gmail.com
}

Received: February 21, 2018

Accepted: March 7, 2018 Published: March 14, 2018

doi:10.5296/ijafr.v8i1.12825

URL: https://doi.org/10.5296/ijafr.v8i1.12825

\begin{abstract}
The propensity of WTO always ensure to strengthening and consolidating the integration approach with country to country. Manifold accession like TRIMS, TRIPS and trade liberalization agenda facilitate to enlarge the attractiveness of foreign direct investment in many more developing countries. This study is concentrates on judgment of the WTO accession like liberalization, TRIMS and TRIPS stimulate the flow of FDI in developing countries and also to observe that the other relevant important variables such as macroeconomic stability, infrastructure, human capital, geographic location, financial development, agglomeration, market size has helped the incessant inflow of FDI for developing country. Some research penetratingly interpreted that TRIMS, TRIPS and trade liberalization accession are controversial subject matter for the developing countries. For accomplishing the research work the paper has used panel data of 58 different developing countries over the years 1990-2014. Through that work the paper has explore that because of the adopting liberalization polices, relinquishing market distortions with the connection of TRIMS and harmonization of IPR standards throughout TRIPS escalate the foreign direct investment in the developing countries, it means that there is a significant relationship of FDI along with TRIPS, TRIMs and trade openness. Other pertinent factors like market size, macroeconomic stability, agglomeration and engagement of WTO membership have also significant impact on FDI inflows. Others common factors like infrastructure, human capital, financial development, geographical location also make significant impact on facilitating foreign direct investment. Developing countries always requires strengthening their superiority and protecting rights and ensuring negotiation process and encouraging market liberalization process for accomplishing economic competitiveness.
\end{abstract}




\section{MlMacrothink}

International Journal of Accounting and Financial Reporting

ISSN 2162-3082

2018, Vol. 8, No. 1

Keywords: WTO, TRIMS, TRIPS, Trade liberalization, IPR, Human capital, Financial Development

\section{Introduction}

Last few decades expertise have observed that developing countries have attempted to adopt the trade liberalization policy and abolish the different trade related impediments for enforcing incessant flow of FDI along with offering manifold incentives to magnetize foreign investors in the enviable sectors. WTO always stimulates the free and open market economy. The principles of World Trade organizations emphasizes on free trade principles, transparency in trade management, removal of trade barriers, preferential treatment for developing countries regarding technology and financial aspects, rule based trading system with competition and environmental protection for sustainable growth (Cherulinam, 2007).

Trade liberalization framework envisioning the developing country to strengthening the economic advancement and ascertain an affirmative environment to make uninterrupted flow of FDI. Using data for 87 countries, Hakura and Jaumotte (1999) find that "trade indeed serves as an important way for the international technology transfer to developing countries. The authors show that intra-industry trade plays a more important role in technology transfer than inter-industry trade. Intra-industry trade is more pervasive among developed countries, and inter- industry is more prominent in trade between developed and developing countries. Developing countries will enjoy relatively less technology transfer from trade than developed countries."

Due to the exploration of new knowledge and enterprising research and development there is an increasing significance of international intellectual property rights (IPRs). TRIPS is mainly incorporated with the trademarks, copyrights, industrial designs, data secrets, and patents. The adoption of the TRIPS Agreement was a major step towards the harmonization of certain aspects of the protection of IPRs. WTO Members have been left room for maneuver to adopt, in certain cases, different approaches and legal solutions (Correa, 2000a). Strengthened IPR protection increases countries' access to foreign technology through trade (Smith, 1999; Fink and Braga, 1999; Maskus and Penubarti, 1995; Rapp and Rozek, 1990), encourage inflow of FDI (Park and Lippoldt, 2007; Javorcik, 2004; Lee and Manseld, 1996; Seyoum, 1996) and licensing activities (Wakasugi, 2007; Yang and Maskus, 2001).

TRIMs agreement may persuade the develop country to ameliorate the awareness to make considerable assurance to surge the investment. Governments always focus on certain conditions on foreign investors to encourage investment in according to certain national priorities. These Conditions which can affect trade are known as trade-related investment measures or TRIMs (Kennedy, 2003). The TRIMs agreement forbids any laws, policies or administrative regulations that favoring domestic products and producers, includes government incentives to encourage corporations to use domestically made products as a way of creating or protecting local jobs. Industrial policy needs to formulate that are commensurate and relevant may augment the domestic competency as well as creating affirmative atmosphere for easy flow of investment. 


\section{Mll Macrothink}

International Journal of Accounting and Financial Reporting

ISSN 2162-3082

2018, Vol. 8, No. 1

WTO always put forward by espousing liberalizing trade policy for accomplishing the integrated and unified market base economy. WTO make intervention in miscellaneous trade dispute related aspects. This study mainly concentrates to make judgment of WTO accession like, liberalization, TRIMS and TRIPS stimulate the flow of FDI and also determining the other relevant important variable such as macroeconomic stability, infrastructure, human capital, geographic location, market size also intensifying the incessant inflow of FDI for developing country.

The following section is incorporated with the literature review, section three covers with the theoretical framework with different variables that influence to flow of FDI, section four covers with the empirical evidence, and section five covers with the conclusion.

\section{Literature Review}

Rapid Trade liberalization policy under the framework of WTO makes this world integrated and inter-related with one to another. There are many drastically transformation after the inception to the WTO, and necessity for discussion came out in Uruguay Round, like TRIPS and TRIMs.

TRIPs supporters argue that strong protection of IPRs would enhance increased flows of FDI and facilitate technology transfer to developing countries, and consequently stimulate local innovation capacity (Correa 2005). Due to the globalization and market base economy generates diffusion of knowledge and continuous product innovation and adaptation of new wisdom and advancement of modern technology is unavoidable for market access. IPR protection is considered as pre-condition for FDI. Economic analysis also shows that sufficient IPRs protection is an essential component of increased inward FDI and trade flows in IPRs-sensitive goods for countries cherishing to make economic development. A country that enhances its IPR regime may attract additional knowledge intensive products, which will otherwise be unavailable on the local market or it may attract FDI; in either case, international technology transfer is likely to flow (Lippoldt, 2006). Lesser (2002), Lee and Mansfield (1996), and Smarzynska (2004) found a positive effect of IPR on FDI.

TRIMS Agreement encompasses not only the promotion of the expansion and progressive liberalization of world trade, but also the facilitation of investment across international frontiers.

Number of challenges face by the developing countries in the phase of implementation, these include the difficulty of identifying TRIMs covered by the agreement and ensuring their timely notification to the WTO, the inadequacy of the transition period for phasing out prohibited TRIMs and disputes arising from the lack of clarity between the GATT, the TRIMs agreement and the Agreement on Subsidies and Countervailing Measures. The biggest concern of the prohibition of local content requirement judgment that many developing countries view that it hampers their economic interest. Developed countries argued that TRIMs represented nothing but host government interference with a liberal trade regime. WTO has pushed developing countries towards free trade by reducing tariffs considerable way and also reducing the government impediment and abolishing government 


\section{Ml Macrothink}

International Journal of Accounting and Financial Reporting

ISSN 2162-3082

2018, Vol. 8, No. 1

regulation regarding foreign direct investment. TRIMS and TRIPS agreement conducts a comprehensive shrinking on FDI related restrictions.

Significant trade liberalization would be one of the driving forces for the rapid increase of FDIs to developing countries. Developing countries are significantly reducing the trade barriers after the engagement of WTO. Trade openness as FDI has become one of the main argument among economist and policy makers in explaining the growth phenomena in developing countries Dawson, (2006). Some studies have found significant positive effects of trade liberalization on FDI (Kandiero and Chitiga, 2006; Addison and Heshmati, 2003; Onyeiwu and Shrestha, 2004; Botric and Skuflic, 2006; Greenaway et al., 2007). Some studies like Razafimahefa and Hamori (2005) argue that liberalization weakly determine FDI.

The effect of trade openness on FDI inflows, proponents for trade openness (Nishimizu and Robinson, 1986; Nishimizu and Page, 1991; Tybout, 1992; Helleiner, 2002) contend that trade openness enhances competition which in turn increases the pressure, increased efficiencies, technical change and product improvement, reduced costs of production, general economic growth via raising profits which encourage growth of foreign capital investment and inflows of expertise, and enhanced equal access to scarce resources which improves the overall resource allocation and eliminates corruption in the system.

It is an inevitable fact that WTO policies always stimulate to consolidate and strengthen the connections with the global market. Some research penetratingly said that the different accession under the WTO always privileged for the developed countries and WTO always using as a term of exploiting resources and generating market seeking ingredient for the MNCs. Here the paper have tried to find out the different accession mainly concentrates on TRIPS, TRIMS and trade liberalization under the WTO facilitated the foreign direct investment for the developing countries.

\section{Theoretical Framework}

Here the basic purpose is to explore the consequence of the implementation of WTO accession like TRIMS, TRIPS and trade liberalization scheme that may facilitate the unremitting flow of FDI in the various developing countries. For identifying the following equation is being constituted.

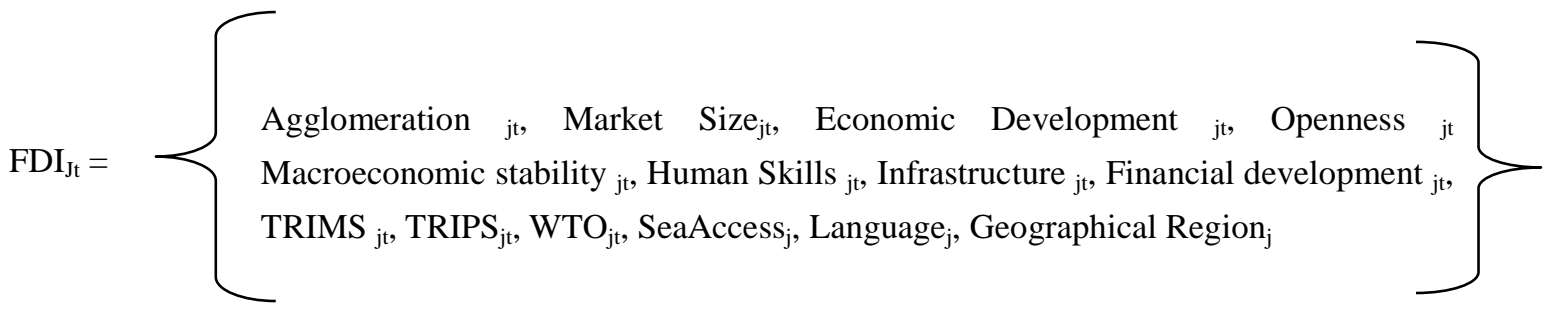

Here ' $\mathrm{j}$ ' represents the developing country and that may vary from 1 to 58 and $\mathrm{t}$ ' represent time tenure which covering the years from 1990 to 2014. The paper has selected a total of $58 * 25=1,450$ observations for each variable included in the sample. 


\section{Macrothink}

International Journal of Accounting and Financial Reporting

At the initial stage the following equation that may partially reflect the first equation,

$F I_{j t}=\beta_{0}+\beta_{1} g_{j t}+\beta_{2}$ Population $_{j t}+\beta_{3}$ Trade $_{j t}+\beta_{4}$ Exchangerate $_{j t}+\beta_{5}$ Skill $_{j t}+\beta_{6}$ Education $_{j t}$

$$
+\beta_{7} \text { FinancialDevelopmeny }_{j t}+\beta_{8} I P R_{j t}+\beta_{9} \text { Sea Access }+\beta_{10} \text { Language }_{j t}+\varepsilon_{j t}
$$

Log linear equation of (2)

$$
\begin{aligned}
\text { lnFDI }_{j t}= & \beta_{0}+\beta_{1} \text { lngjt }+\beta_{2} \ln \text { Population }+\beta_{3} \text { lnTradejt }+\beta_{4} \ln \text { Exchangeratejt }+\beta_{5} \ln \text { Skilljt } \\
& +\beta_{6} \text { lnEducationjt }+\beta_{7} \text { lnFinancialDevelopmenyjt }+\beta_{8} \text { InIPRjt }+\beta_{9} \text { Sea Access } \\
& +\beta_{10} \text { Language }_{j t}+\varepsilon_{j}
\end{aligned}
$$

But the equation (3) may not serve the purpose that's why the paper requires formulating another equation that may effect of TRIMS and TRIPS. Here is the following equation.

$$
\begin{aligned}
\text { Fdi }_{j t} & =\alpha_{0}+\beta_{1} \text { Fdi }_{j t-1}+\beta_{2} \text { Population }_{j t}+\beta_{3} \text { Gdppc }_{j t}+\beta_{4} \text { Trade }_{j t}+\beta_{5} \text { Exchagerate }_{j t}+\beta_{6} \text { GSEP }_{j t} \\
& +\beta_{7} \text { TeleDensity }_{j t}+\beta_{8} \text { FinancialDevelopmennt }_{j t}+\beta_{9} \text { Trade Agreement }_{j t}+\beta_{10} \text { Patent }_{j t} \\
& +\beta_{11} \text { Region }_{j}+\beta_{12} \text { Language }_{j}+\beta_{13} \text { Sea Access }_{j}+\varepsilon_{j}
\end{aligned}
$$

Log Linear equation 4 that replacing the variable with an appropriate proxy from the Equation

$$
\begin{aligned}
\text { lnFdi }_{j t}= & \alpha_{0}+\beta_{1} \text { InFdi }_{j t-1}+\beta_{2} \text { InPopulation }_{j t}+\beta_{3} \text { lnGdppc }_{j t}+\beta_{4} \text { InTrade }_{j t}+\beta_{5} \text { InExchagerate }_{j t} \\
& +\beta_{6} \text { InGSEP }_{j t}+\beta_{7} \text { InTeleDensity }_{j t}+\beta_{8} \text { InFinancialDevelopmennt } \\
& +\beta_{9} \text { InTrade Agreement }_{j t}+\beta_{10} \text { InPatent }_{j t}+\beta_{11} \text { Region }_{j}+\beta_{12} \text { Language }_{j} \\
& +\beta_{13} \text { Sea Access }_{j}+\varepsilon_{j}
\end{aligned}
$$

Here is the dependent variable is Stock Inward FDI and the independent variables are lag FDI Stock, Gross domestic product \& Population, Gross domestic product per capita, GDPPC adjusted for purchasing power parity \& gross fixed capital formation per capita, Aggregate trade as a percentage of GDP, Exchange Rate, Skill Level, Infrastructure, Financial development and trade liberalization, Trade Agreements ,Patents, Trademarks and Industrial Design, WTO membership, Language, Sea Access, Geographical and Income groups. 


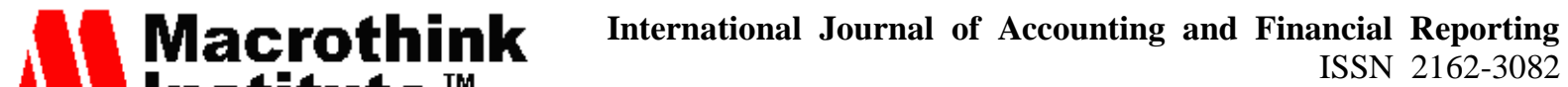 \\ 2018, Vol. 8, No. 1}

Table 1. Expected Sign of the different independent variables

\begin{tabular}{|c|c|c|}
\hline Variables & Description & $\begin{array}{l}\text { Expected } \\
\text { Sign }\end{array}$ \\
\hline Market Size & $\begin{array}{l}\text { Jordan (2004) mentioned that FDI will move to countries with larger and expanding } \\
\text { markets and greater purchasing power, where firms can potentially receive a higher return } \\
\text { on their capital and by implication receive higher profit from their investment. }\end{array}$ & $(+)$ \\
\hline Economic Development & $\begin{array}{l}\text { Inward flows of FDI not only increase the chances of boosting the available resources, but } \\
\text { also enhance the efficiency of the local resources. (El-Fergani, 2003). }\end{array}$ & $(+)$ \\
\hline Agglomeration & $\begin{array}{l}\text { Strong agglomeration effects are found on FDI inflows ( } \mathrm{Li} \text { et al. 2010). } \\
\text { Xu (2000), Benhabib and Speigel (1994), and Borensztein, De Gregorio, and Lee (1998) } \\
\text { argue that even though FDI promotes technology transfer, the higher productivity in the }\end{array}$ & $(+)$ \\
\hline $\begin{array}{l}\text { Human Capital } \\
\text { Infrastructure }\end{array}$ & $\begin{array}{l}\text { host country only holds when a minimal level of educational attainment is achieved. } \\
\text { Mollick et al. (2006) analyzed the role of telecommunications (telephone lines) and } \\
\text { transport infrastructure (roads) for FDI and find a positive impact of both types of } \\
\text { infrastructure. }\end{array}$ & $(+)$ \\
\hline $\begin{array}{l}\text { Macroeconomic } \\
\text { Stability }\end{array}$ & $\begin{array}{l}\text { Countries with a high degree of currency risk will lose out on FDI to countries with more } \\
\text { stable currencies (Foad 2005). }\end{array}$ & $(+,-)$ \\
\hline Financial Development & $\begin{array}{l}\text { Claessens, Klingebiel, and Schmukler (2001), argued that since FDI is positively correlated } \\
\text { with stock market capitalization and value traded, then FDI is a complement and not a } \\
\text { substitute of domestic stock market development }\end{array}$ & $(+)$ \\
\hline Geographical Location & $\begin{array}{l}\text { Galan et al. (2007) recognize that the FDI motive of MNEs is the prerequisite of location } \\
\text { choice, and MNEs make decisions by linking the evaluation of advantages (characteristics) } \\
\text { of a destination with specific motives. }\end{array}$ & $(+)$ \\
\hline Language & $\begin{array}{l}\text { Multinational enterprises (MNEs) have increasingly broadened their use of foreign direct } \\
\text { investment (FDI), and as a result they often need to deal with multiple languages and the } \\
\text { associated administrative and transactions costs that come with language differences (Luo } \\
\text { and Shenkar, 2006). }\end{array}$ & $(+)$ \\
\hline TRIMS & $\begin{array}{l}\text { Li Hai -Qing (2001) has explained that the purpose of TRIMs is to use FDI measures to } \\
\text { attract FDI or direct FDI in a way that is beneficial to host country's domestic industries and } \\
\text { trade performance. }\end{array}$ & $(+)$ \\
\hline TRIPS & $\begin{array}{l}\text { IPRs positively affect the volume of FDI by enabling foreign firms to compete effectively } \\
\text { with indigenous firms that possess ownership advantages (Smarzynska Javorcik, 2004). }\end{array}$ & $(+)$ \\
\hline Trade Openness & $\begin{array}{l}\text { Trade openness helps to ensure the growth phenomena in developing countries (Dawson, } \\
\text { 2006). }\end{array}$ & $(+)$ \\
\hline WTO Membership & $\begin{array}{l}\text { Felbermayr and Kohler (2007) focus on the WTO effect on trade. Using a combination of a } \\
\text { Probit model and a Tobit model, they find that when both countries are WTO members, } \\
\text { their trade is } 31 \text { percent higher than it would otherwise be and that the effects of GATT } \\
\text { participation are greater when one economy is a member than when both are members. }\end{array}$ & $(+)$ \\
\hline
\end{tabular}

\section{Empirical Evidence}

The following table explains that whether the variables are stationary or not. For 


\section{Macrothink \\ International Journal of Accounting and Financial Reporting \\ ISSN 2162-3082 \\ 2018, Vol. 8, No. 1}

accomplishing the tasks panel unit root test is being accomplished. According to the table the level of all the series do not include unit root at $1 \%$ significance level. It indicates that the time series are stationary.

Table 2. Panel unit root test

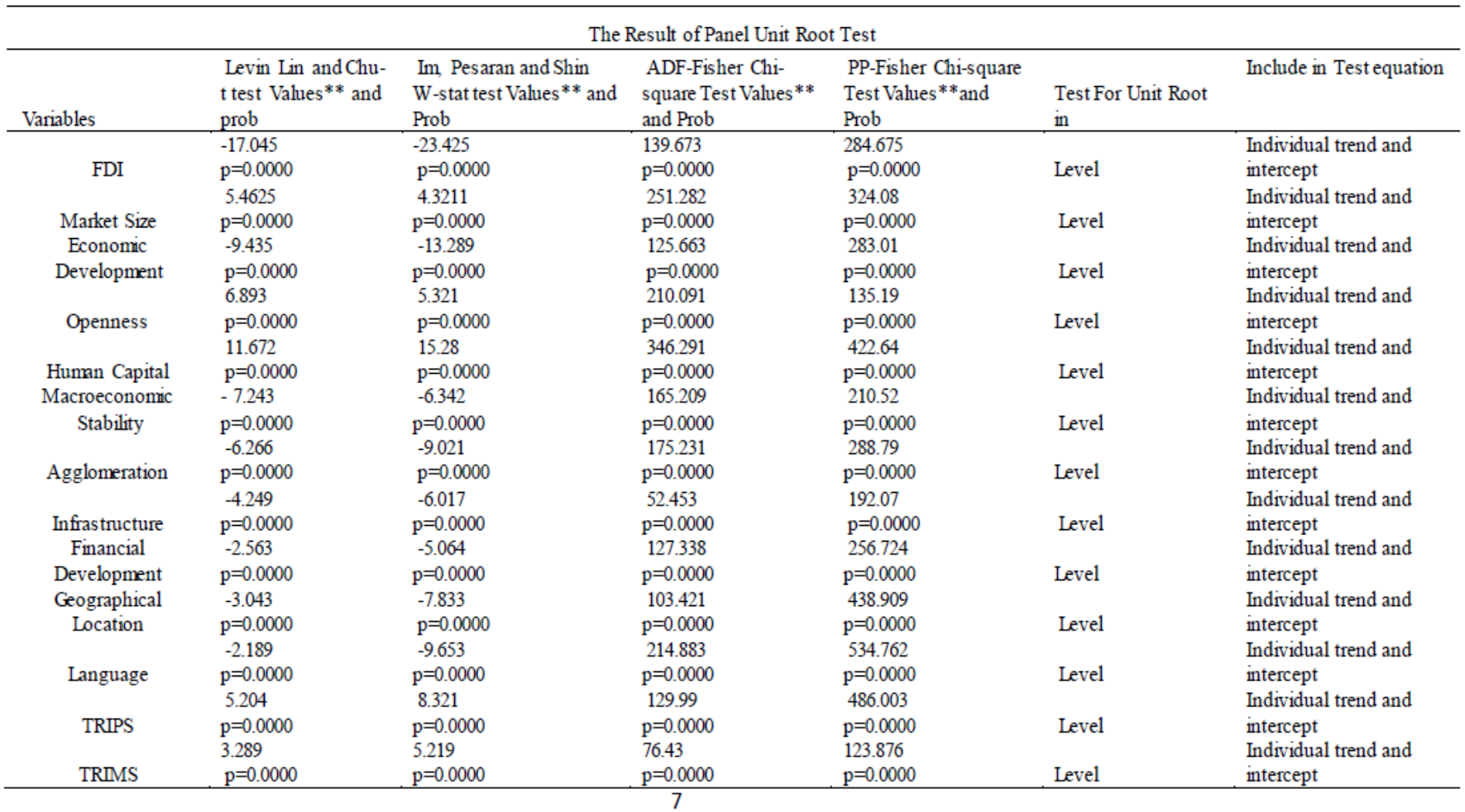

The following table explained the descriptive statistics. The mean of a data explain the average value of the data set. The median of a data set is the value in the middle when the data are organized in ascending order. On the other hand the standard deviation of a data set is the positive square root of the variance.

Table 3. Summary statistics

\begin{tabular}{lcrrrr}
\hline & & \multicolumn{2}{c}{ Standard } \\
Variable Name & No of Observation & Mean Value & Deviation & Minimum Value & Maximum Value \\
\hline LnFDI Stock & 1450 & 19.45 & 3.59 & 5.23 & 35.29 \\
LnGDP & 1450 & 17.25 & 2.52 & 11.43 & 32.78 \\
Ln Population & 1450 & 9.25 & 2.81 & 9.81 & 29.80 \\
LnGDPPC & 1450 & 4.11 & 2.05 & 6.23 & 12.43 \\
LnGDPPCPPP & 1450 & 5.32 & 2.11 & 7.28 & 12.65
\end{tabular}




\section{Ml Macrothink}

International Journal of Accounting and Financial Reporting

ISSN 2162-3082

LnGFCFPC

LnTrade\% GDP

Ln Exchange Rate

Ln Inflation

Ln Labour

LnGDPPW

LnGFCFPW

LnGSEPP

LnGSEP

LnGSES

LnGSET

Ln Literacy Rate

Average Years of Schooling

Ln Tele-Density

LnGFCF

DSBS\%GDP
DCPS\%GDP
M3\%GDP

LnLDCT

MCLC\%GDP

Financial Development

Ln Trade Agreement

Ln Enforced Trade

Agreements

Ln Trade Marks

Ln Total Industry Design

Ln Resident Industrial

Design

Ln Non-Res Industrial

Design

Ln Total Patents

Ln Resident Patents

Ln Non-resident Patents

Ginarte \& Park Index
1450

1450

1450

1450

1380

1380

1380

850

1450

1450

850

1050

1050

1450

1450

1350

1350

900

800

800

1450

1450

1450

1450

1450

1450

1450

1450

1450

1450

1000
4.51

3.23

4.62

5.33

9.39

5.45

4.22

2.47

2.69

2.41

4.28

3.85

4.22

5.65

7.29

11.35

11.12

15.09

11.17

14.25

10.23

9.05

8.32

5.57

4.23

3.29

3.48

5.20

6.31

4.87

5.93 2018, Vol. 8, No. 1

1.29

3.66

1.23

5.06

12.93

4.28

1.43

0.92

3.29

2.61

0.75

2.09

0.88

1.29

1.48

89.62

0.85

8.29

1.89

1.94

9.67

1.22

1.15

9.47

1.14

1.04

1.09

19.73

1.08

1.04

18.45

2.03

1.07

29.59

1.45

1.23

19.26

1.83

1.31

25.88

0.48

19.53

1.26

1.09

25.73

1.19

1.25

8.29 
Table 4. Correlation Matrix

\begin{tabular}{|c|c|c|c|c|c|c|c|c|c|c|c|c|c|c|c|c|c|c|c|c|c|c|c|c|c|c|c|c|c|c|c|}
\hline Variable & 1 & 2 & 3 & 4 & 5 & 6 & 7 & 8 & 9 & 10 & 11 & 12 & 13 & 14 & 15 & 16 & 17 & 18 & 19 & 20 & 21 & 22 & 23 & 24 & 25 & 26 & 27 & 28 & 29 & 30 & 31 \\
\hline $\ln F D I S t$ & 100 & & & & & & & & & & & & & & & & & & & & & & & & & & & & & & \\
\hline Inpop & 72 & 100 & & & & & & & & & & & & & & & & & & & & & & & & & & & & & \\
\hline Ingdppc & 43 & 9 & 100 & & & & & & & & & & & & & & & & & & & & & & & & & & & & \\
\hline InT rade & 13 & 14 & 32 & 100 & & & & & & & & & & & & & & & & & & & & & & & & & & & \\
\hline $\ln \operatorname{Inf}$ & 11 & 19 & 17 & 13 & 100 & & & & & & & & & & & & & & & & & & & & & & & & & & \\
\hline $\ln \mathrm{Xrat}$ & -13 & 7 & -23 & -11 & 18 & 100 & & & & & & & & & & & & & & & & & & & & & & & & & \\
\hline $\ln L a b$ & 72 & 69 & 10 & 29 & 23 & 8 & 100 & & & & & & & & & & & & & & & & & & & & & & & & \\
\hline Ingsepp & 69 & 18 & 67 & 15 & 32 & 42 & 23 & 100 & & & & & & & & & & & & & & & & & & & & & & & \\
\hline lngsep & 56 & 26 & 58 & 22 & 18 & -11 & 17 & 57 & 100 & & & & & & & & & & & & & & & & & & & & & & \\
\hline Ingses & 61 & 22 & 72 & 35 & 20 & 47 & 17 & 67 & 61 & 100 & & & & & & & & & & & & & & & & & & & & & \\
\hline $\begin{array}{l}\text { Ingset } \\
\text { Lnlit }\end{array}$ & $\begin{array}{l}58 \\
67\end{array}$ & $\begin{array}{l}26 \\
13\end{array}$ & $\begin{array}{l}79 \\
63\end{array}$ & $\begin{array}{l}23 \\
33\end{array}$ & $\begin{array}{l}31 \\
24\end{array}$ & $\begin{array}{l}32 \\
18\end{array}$ & $\begin{array}{l}11 \\
13\end{array}$ & $\begin{array}{l}56 \\
73\end{array}$ & $\begin{array}{l}54 \\
83\end{array}$ & $\begin{array}{l}74 \\
72\end{array}$ & $\begin{array}{c}100 \\
71\end{array}$ & 100 & & & & & & & & & & & & & & & & & & & \\
\hline $\begin{array}{l}\text { AvgYrsSc } \\
\text { lnTele } \\
\text { Ingfef }\end{array}$ & $\begin{array}{l}72 \\
82 \\
85\end{array}$ & $\begin{array}{l}14 \\
74 \\
82\end{array}$ & $\begin{array}{l}72 \\
67 \\
62\end{array}$ & $\begin{array}{l}45 \\
11 \\
26\end{array}$ & $\begin{array}{l}20 \\
18 \\
23\end{array}$ & $\begin{array}{r}-12 \\
23 \\
-24\end{array}$ & $\begin{array}{l}10 \\
49 \\
82\end{array}$ & $\begin{array}{l}62 \\
55 \\
45\end{array}$ & $\begin{array}{l}67 \\
59 \\
54\end{array}$ & $\begin{array}{l}85 \\
65 \\
64\end{array}$ & $\begin{array}{l}82 \\
65 \\
66\end{array}$ & $\begin{array}{l}83 \\
66 \\
62\end{array}$ & $\begin{array}{r}100 \\
51 \\
46\end{array}$ & $\begin{array}{r}100 \\
72\end{array}$ & 100 & & & & & & & & & & & & & & & & \\
\hline $\mathrm{Fd}$ & 59 & 28 & 57 & 37 & 17 & 21 & 30 & 54 & 41 & 55 & 45 & 45 & 49 & 48 & 54 & 100 & & & & & & & & & & & & & & & \\
\hline Lnta & 63 & 35 & 59 & 11 & 9 & 31 & 17 & 52 & 29 & 51 & 52 & 42 & 40 & 56 & 59 & 29 & 100 & & & & & & & & & & & & & & \\
\hline Lntm & 67 & 63 & 47 & 18 & 28 & 41 & 63 & 51 & 49 & 52 & 52 & 41 & 41 & 59 & 75 & 38 & 45 & 100 & & & & & & & & & & & & & \\
\hline $\ln \mathrm{Tid}$ & 65 & 68 & 48 & -17 & 9 & 15 & 54 & 50 & 34 & 43 & 51 & 35 & 42 & 67 & 79 & 34 & 67 & 72 & 100 & & & & & & & & & & & & \\
\hline $\ln R \mathrm{id}$ & 68 & 67 & 42 & 15 & 11 & 17 & 68 & 42 & 43 & 41 & 45 & 32 & 45 & 63 & 70 & 32 & 55 & 70 & 83 & 100 & & & & & & & & & & & \\
\hline $\ln$ Nrid & 67 & 62 & 53 & -14 & 10 & 22 & 49 & 49 & 41 & 45 & 48 & 39 & 41 & 67 & 73 & 38 & 59 & 75 & 85 & 82 & 100 & & & & & & & & & & \\
\hline $\ln T_{p}$ & 66 & 61 & 56 & -23 & 10 & 31 & 61 & 45 & 40 & 48 & 49 & 38 & 48 & 62 & 72 & 39 & 55 & 74 & 74 & 84 & 73 & 100 & & & & & & & & & \\
\hline $\ln R p$ & 69 & 66 & 45 & -22 & 8 & -21 & 66 & 43 & 35 & 45 & 43 & 32 & 39 & 63 & 77 & 43 & 49 & 69 & 76 & 75 & 76 & 83 & 100 & & & & & & & & \\
\hline $\ln N r p$ & 68 & 62 & 51 & 19 & 11 & -32 & 42 & 41 & 38 & 48 & 49 & 38 & 41 & 65 & 73 & 46 & 52 & 69 & 72 & 77 & 75 & 82 & 83 & 100 & & & & & & & \\
\hline$G \& P$ & 63 & 23 & 55 & 22 & 11 & -13 & 37 & 45 & 29 & 42 & 50 & 43 & 50 & 55 & 59 & 48 & 59 & 25 & 59 & 47 & 46 & 25 & 33 & 22 & 100 & & & & & & \\
\hline WTO & 35 & 14 & 16 & 26 & 14 & 18 & 18 & 16 & 12 & 14 & 14 & 11 & 23 & 35 & 14 & 19 & 49 & 16 & 32 & 9 & 21 & -13 & 3 & 11 & 42 & 100 & & & & & \\
\hline SA & 15 & 45 & 18 & 29 & -7 & 11 & 43 & 19 & -10 & -12 & -19 & -19 & -23 & 29 & 28 & 15 & 28 & 14 & 31 & 29 & 25 & 23 & 26 & 18 & 21 & 10 & 100 & & & & \\
\hline LAC & 31 & -29 & 21 & 11 & 18 & 21 & 29 & 55 & 46 & 55 & 59 & 65 & 55 & 19 & 22 & -18 & 32 & 23 & 18 & 11 & 26 & 29 & 11 & 17 & 27 & 9 & 12 & 100 & & & \\
\hline Sea & 48 & 24 & 32 & 28 & 13 & -31 & 23 & 54 & 43 & 51 & 47 & 52 & 35 & 28 & 51 & 24 & 16 & 34 & 38 & 35 & 27 & 29 & 23 & 22 & 11 & -10 & 11 & 13 & 100 & & \\
\hline English & 14 & 17 & 19 & 19 & 7 & -15 & 17 & 23 & 12 & 14 & 19 & 19 & 14 & 14 & 10 & 39 & -19 & 16 & 11 & -3 & -19 & 11 & -6 & -3 & 9 & 18 & 35 & 12 & 16 & 100 & \\
\hline French & -32 & -29 & 38 & -10 & -23 & -21 & -31 & -21 & -27 & -34 & -51 & -41 & -51 & -43 & -56 & -32 & -28 & -44 & -28 & -23 & -32 & -34 & -39 & -45 & -22 & -23 & -15 & -41 & -23 & -29 & 100 \\
\hline
\end{tabular}

From the Table 4, the paper has seen that high correlations between explanatory variables are observed. From the Table 5, the paper has seen that the coefficient for the market size variable is positive and significant as expected. The size of the FDI large extent relies on the market size in host country, so it is expected that there is an association between the market size and FDI. Gross domestic product per capital (GDPPC) is the proxy for economic development which is also positive and statistically significant and that happened because foreign direct investment is responsive to gross domestic product per capital in the host developing country. Openness is observed to be positively and significantly associated to FDI inflows. On the other hand the coefficient macroeconomic stability such as inflation and exchange rate are being treated as a proxy for macroeconomic stability. The coefficient for inflation is statistically negative that indicates an increase in consumer prices causes a decrease in inward FDI. So that from the result it can pronounce that high inflation escort to low FDI and low inflation spawn high FDI. Another proxy variable exchange rate for macroeconomic stability also exhibits statistically significant that point out devaluation stimulates a diminishing local production will augmented the flow of FDI and appreciation will adverse consequences on inflow of FDI in host countries. In the human capital variable the paper has used six different educational measures. From that measure it can see that gross school enrolment in pre-primary level and literacy rate are insignificant but rest of the measure are statistically significant. Human capital investment was a statistically significant determinant of FDI inflows; it is one of the most important determinants of FDI inflow and that over time human capital would assume an even greater impact on FDI. The coefficient 
for tele-density used as a proxy for infrastructure is also find out to be positive and statistically significant at $1 \%$ significance level because availability of better communication infrastructure that lead investors to choose a particular location. Financial development is a significant element for attracting FDI also. Above mentioned estimation demonstrate that host countries market size, economic development, macroeconomic stability, human capital and infrastructure are the inseparable and distinctive function for conglomeration of substantial amount of FDI for host developing country.

Table 5. Estimation result- controlling for conventional FDI location pull factor

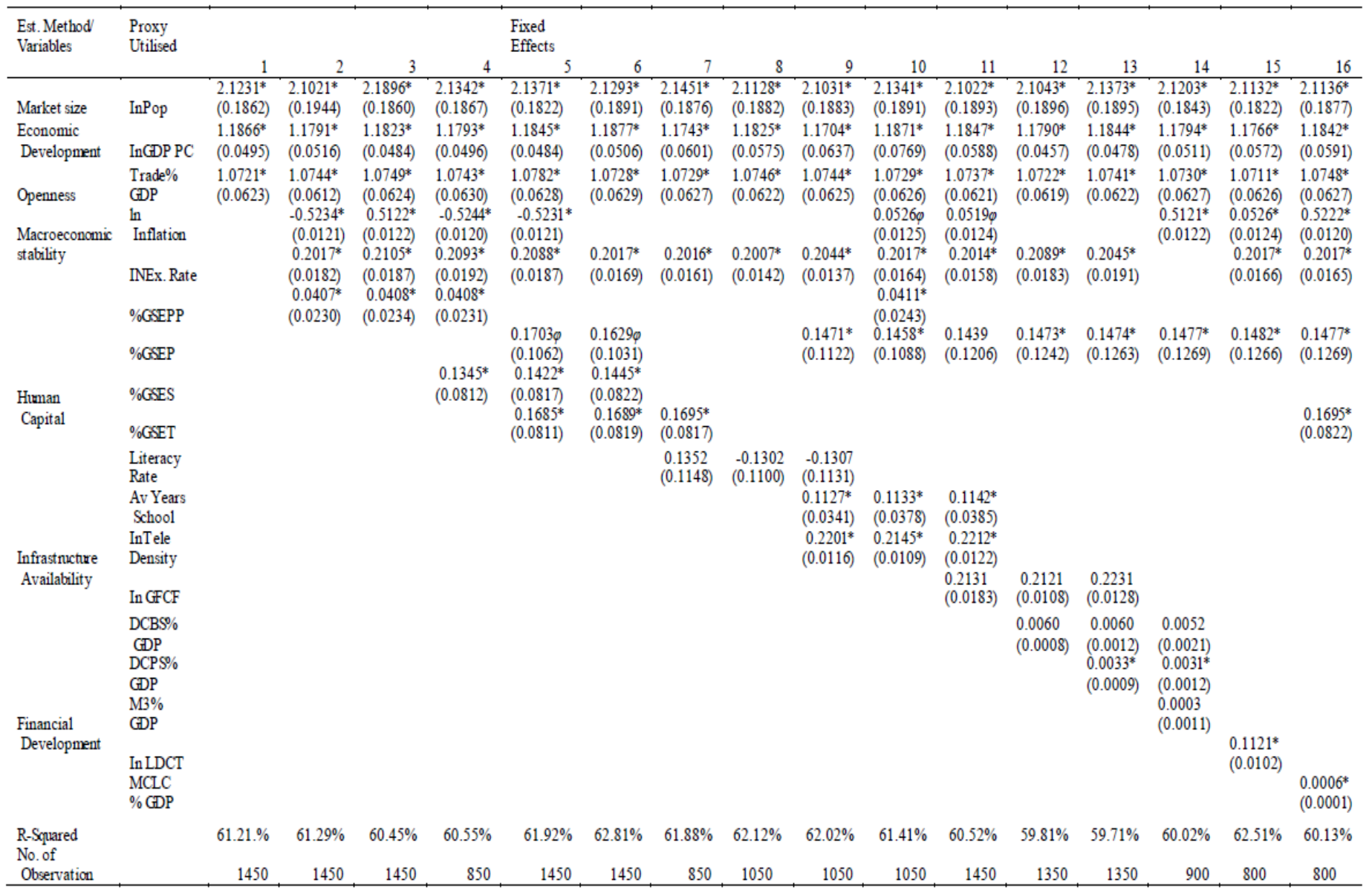

In the Table 6, the paper has elucidated the baseline model again; here it incorporated the number of trade agreement as a proxy for TRIMS. It also find out to be significant at $1 \%$ level and positive coefficient demonstrate that an increase in the number of trade agreements signed by the host causes additional inward FDI. Also evident from the table it is also explicate that the openness depleted from 0.92 to 0.81 with the introduction of TRIMS as a proxy. TRIMs Agreement is to promote the expansion and liberalization of world trade and to facilitate investment across international frontiers so as to increase the economic growth of all trading partners, particularly developing country Members, while ensuring free 
competition. Developing country governments have deliberately thought that TRIMs counter the trade-restrictive and trade-distorting strategies of transnational corporations but here it is explore that preferential treatment may allow to engender substantial amount of FDI for developing country.

Here the paper has also test for the effects of TRIPS on enhancing a developing country's inward FDI potential. The coefficients for total trade marks, total and non-resident patents and Ginarte and Park index are positively significant at $1 \%$ level. IPR protection is considered as pre-condition for FDI. Economic analysis also shows that sufficient IPRs protection is an essential component of increased inward FDI and trade flows in IPRs-sensitive goods for countries cherishing to make economic development since the IPRs-initiated FDI brings in investment securities for IPRs-owning countries through effective rent payments. Implementing the TRIPS agreement will augment the capabilities for attracting more $F D I$ and also enhance the shielding measure that spiraling MNCs to defend their market share. So from the table 6,it has explored that there is an affirmative consequence of a larger market, degree of development, market liberalization, macroeconomic stability, TRIMS and TRIPS on FDI for developing country.

Table 6. Estimation result-controlling for the three major wto components i-e trims, trips and liberalization

\begin{tabular}{|c|c|c|c|c|c|c|c|c|c|c|c|c|}
\hline \multirow[t]{2}{*}{$\begin{array}{l}\text { Estimation } \\
\text { Method }\end{array}$} & Proxy & \multicolumn{11}{|c|}{ Fixed Effect } \\
\hline & Variables & 1 & 2 & 3 & 4 & 5 & 6 & 7 & 8 & 9 & 10 & 11 \\
\hline & Ln & $1.1311^{*}$ & $1.1615^{*}$ & $1.1211^{*}$ & $1.3121^{*}$ & $1.2111^{*}$ & 1.1131* & $1.1432^{*}$ & $1.1921^{*}$ & $1.1231^{*}$ & $1.1321^{*}$ & $1.1341^{*}$ \\
\hline Market Size & Population & $(0.1011)$ & $(0.1002)$ & (0.1013) & $(0.1011)$ & $(0.1031)$ & (0.1004) & (0.1031) & (0.1011) & (0.1019) & (0.1009) & (0.1119) \\
\hline Economic & Ln & $1.1121^{*}$ & $1.1231^{*}$ & $1.1544^{*}$ & $1.1210^{*}$ & $1.1101^{*}$ & $1.1552^{*}$ & $1.1518^{*}$ & $1.2211^{*}$ & $1.2263^{*}$ & $1.1511^{*}$ & 1.1211* \\
\hline \multirow[t]{2}{*}{ Development } & GDPPC & $(0.0531)$ & $(0.0511)$ & $(0.0523)$ & $(0.0529)$ & $(0.0564)$ & $(0.0501)$ & $(0.0503)$ & $(0.0521)$ & $(0.0535)$ & $(0.0521)$ & $(0.0531)$ \\
\hline & Trade $\%$ & $0.8142^{*}$ & $0.8022^{*}$ & $0.84032^{*}$ & $0.7812^{*}$ & $0.7834^{*}$ & $0.8013^{*}$ & $0.7904^{*}$ & $0.7913^{*}$ & $0.7751^{*}$ & $0.7932^{*}$ & $0.7948^{*}$ \\
\hline Openness & $\mathrm{GDP}$ & $(0.0785)$ & $(0.0795)$ & $(0.0799)$ & $(0.0794)$ & $(0.0808)$ & $(0.0812)$ & $(0.0812)$ & $(0.0795)$ & $(0.0796)$ & $(0.0795)$ & $(0.0853)$ \\
\hline $\begin{array}{l}\text { Macroeconomic } \\
\text { Stability }\end{array}$ & $\begin{array}{l}\text { Exchange } \\
\text { Rate }\end{array}$ & $\begin{array}{l}0.1942^{*} \\
(0.0142)\end{array}$ & $\begin{array}{l}0.1918^{*} \\
(0.0139)\end{array}$ & $\begin{array}{l}0.2001^{*} \\
(0.0149)\end{array}$ & $\begin{array}{l}0.1961^{*} \\
(0.0144)\end{array}$ & $\begin{array}{l}0.1904^{*} \\
(0.0148)\end{array}$ & $\begin{array}{l}0.1944^{*} \\
(0.0147)\end{array}$ & $\begin{array}{l}0.1932^{*} \\
(0.0142)\end{array}$ & $\begin{array}{l}0.1928^{*} \\
(0.0142)\end{array}$ & $\begin{array}{l}0.1917^{*} \\
(0.0141)\end{array}$ & $\begin{array}{l}0.1923^{*} \\
(0.0142)\end{array}$ & $\begin{array}{l}0.1922^{*} \\
(0.0143)\end{array}$ \\
\hline \multirow[t]{2}{*}{ Human Capital } & Education & $\begin{array}{l}0.2745 \varphi \\
(0.1375)\end{array}$ & $\begin{array}{l}0.2658 \varphi \\
(0.1368)\end{array}$ & $\begin{array}{l}0.2784 \varphi \\
(0.1368)\end{array}$ & $\begin{array}{l}0.2673 \varphi \\
(0.1371)\end{array}$ & $\begin{array}{l}0.2681 \varphi \\
(0.1369)\end{array}$ & $\begin{array}{l}0.2691 \alpha \\
(0.1368)\end{array}$ & $\begin{array}{l}0.2788 \alpha \\
(0.1368)\end{array}$ & $\begin{array}{l}0.2741 \alpha \\
(0.1367)\end{array}$ & $\begin{array}{l}0.2894 \alpha \\
(0.1369)\end{array}$ & $\begin{array}{l}0.2762 \varphi \\
(0.1367)\end{array}$ & $\begin{array}{l}0.2706 \varphi \\
(0.1418)\end{array}$ \\
\hline & Tas & & $\begin{array}{l}0.3105^{*} \\
(0.0532)\end{array}$ & $\begin{array}{l}0.3022^{*} \\
(0.0521)\end{array}$ & $\begin{array}{l}0.3041^{*} \\
(0.0541)\end{array}$ & $\begin{array}{l}0.3036^{*} \\
(0.0544)\end{array}$ & $\begin{array}{l}0.3039^{*} \\
(0.0545)\end{array}$ & $\begin{array}{l}0.3025^{*} \\
(0.0547)\end{array}$ & $\begin{array}{l}0.3038^{*} \\
(0.0545)\end{array}$ & $\begin{array}{l}0.3044^{*} \\
(0.0546)\end{array}$ & $\begin{array}{l}0.3029^{*} \\
(0.0547)\end{array}$ & $\begin{array}{l}0.3041^{*} \\
(0.0546)\end{array}$ \\
\hline \multirow{4}{*}{ TRIPS } & $\begin{array}{l}\text { Trade } \\
\text { Marks }\end{array}$ & & & & $\begin{array}{l}0.0231^{*} \\
(0.0109)\end{array}$ & & & & & & & \\
\hline & $\begin{array}{l}\text { Industrial } \\
\text { Design }\end{array}$ & & & & & $\begin{array}{l}-9.83 \mathrm{E}- \\
05\end{array}$ & $\begin{array}{l}0.0121 \\
(0.0008)\end{array}$ & $\begin{array}{l}0.0110 \\
(0.0014)\end{array}$ & & & & \\
\hline & Patents & & & & & & & & $\begin{array}{l}0.0213^{*} \\
(0.0086)\end{array}$ & $\begin{array}{l}0.0211^{*} \\
(0.0063)\end{array}$ & $\begin{array}{l}0.0203^{*} \\
(0.0071)\end{array}$ & $\begin{array}{l}0.0213^{*} \\
(0.0088)\end{array}$ \\
\hline & G\&P Index & & & & & & & & & & $\begin{array}{r}0.2788^{*} \\
(0.0219)\end{array}$ & $\begin{array}{l}0.2876^{*} \\
(0.0206)\end{array}$ \\
\hline R-Squared & R-Squared & $61.22 \%$ & $64.73 \%$ & $63.11 \%$ & $63.26 \%$ & $63.45 \%$ & $64.22 \%$ & $64.45 \%$ & $64.52 \%$ & $64.53 \%$ & $64.77 \%$ & $64.86 \%$ \\
\hline $\begin{array}{l}\text { No of } \\
\text { Observation }\end{array}$ & $\begin{array}{l}\text { Number of } \\
\text { observation }\end{array}$ & 1450 & 1450 & 1450 & 1450 & 1450 & 1450 & 1450 & 1450 & 1450 & 1450 & 1450 \\
\hline
\end{tabular}




\section{MInstitute Macrothink $_{\text {Int }}$}

International Journal of Accounting and Financial Reporting

ISSN 2162-3082

From the Table 7, the paper has introduced the WTO as dummy, it is significant at $1 \%$ level and the positive coefficient shows that it directs swell in inward FDI. It condenses the individual coefficients of trade openness from 0.89 to 0.84 and that of TRIMS from 0.50 to 0.24 , showing that they were partly representing the WTO effect. TRIPS coefficient which is doubles from 0.02 to 0.04 and its significance level increases from 5\% to $1 \%$. This make obvious that WTO association escort to escalation of IPRs in the developing countries and accelerates their FDI. World Trade Organization (WTO) agreement caused overall global trade liberalization and the inclusion of TRIMS and TRIPS agreements facilitate to decelerated the trade related impediments for proliferation of FDI along with an apropos and commensurate improved their intellectual property rights standards resulting increase the inflow of FDI. Geographic location coefficient also find out statistically significant and positive. Because location is an important ingredient when a company gains from its presence in a given market by benefiting from conditions such as: special tax regimes; lower production and transport costs; market size; access to protected markets, and lower risk. Access to sea has a significant effect and the positive coefficient exhibits that a host country is expected to receive more inward FDI if it is not landlocked. Sea ports that alleviate the ocean transportation cost and increase the importance for conducting the transaction and transferring the goods.

Here the paper has also included the language as dummy is significantly negative. The non-resident (foreign) patents as a control variable for TRIPS, however, the same results can be observed like total trademarks, total patents and Ginarte and Park index.

Table 7. Estimation result-controlling for WTO membership and time invariant phenomenon

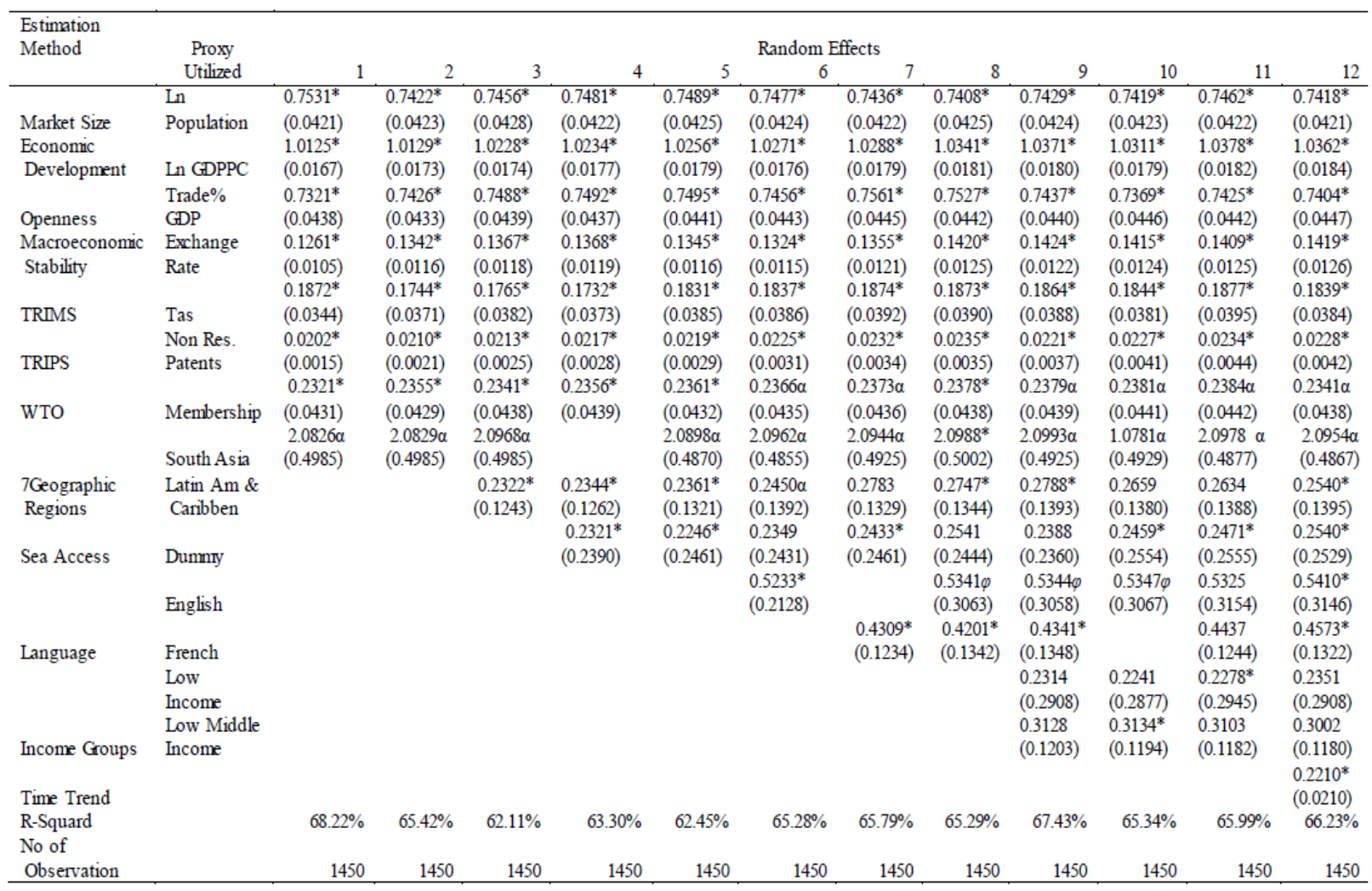




\section{Mll Macrothink}

International Journal of Accounting and Financial Reporting

ISSN 2162-3082

Table 8 interpreted that the lagged value of FDI accumulated stock as a proxy. The coefficient for agglomeration is strongly positive in all the specifications. Strong agglomeration effects are found on FDI inflow. Increasing the number of firms in a specific location stimulating to reduce the cost of production and accumulating manifold skills for the indigenous local producers and MNC having a conducive environment for economic scale and avenue for differentiating their products. Market size, economic development, liberalization, TRIMS, TRIPS (patents) still exerts a significant effect; whereas, labor skills and macroeconomic stability are sensitive to specifications because of this significant and positive effect on FDI, agglomeration may be diverted as a significant effect.

Table 8. Estimation result-dynamic mode

\begin{tabular}{|c|c|c|c|c|c|c|c|c|c|c|c|c|}
\hline \multirow{3}{*}{$\begin{array}{l}\text { Estimation } \\
\text { Method/Variables }\end{array}$} & \multirow{3}{*}{$\begin{array}{c}\text { Proxy } \\
\text { Utilized }\end{array}$} & \multirow{2}{*}{\multicolumn{11}{|c|}{ Arellano-Bover/Blundell-Bond }} \\
\hline & & & & & & & & & & & & \\
\hline & & 1 & 2 & 3 & 4 & 5 & 6 & 7 & 8 & 9 & 10 & 11 \\
\hline \multirow{2}{*}{ Agglomeration } & LFDI Stock & $\begin{array}{l}0.8123^{*} \\
(0.0071)\end{array}$ & $\begin{array}{l}0.8145^{*} \\
(0.0072)\end{array}$ & $\begin{array}{l}0.8122^{*} \\
(0.0071)\end{array}$ & $\begin{array}{l}0.8171^{*} \\
(0.0068)\end{array}$ & $\begin{array}{l}0.8323^{*} \\
(0.0074)\end{array}$ & $\begin{array}{l}0.8321^{*} \\
(0.0073)\end{array}$ & $\begin{array}{l}0.8341^{*} \\
(0.0072)\end{array}$ & $\begin{array}{l}0.8211^{*} \\
(0.0071)\end{array}$ & $0.8355^{*}$ & $0.8331^{*}$ & $0.8362^{*}$ \\
\hline & Ln & $0.4531^{*}$ & $0.4451^{*}$ & $0.4649^{*}$ & $\begin{array}{l}0.0088) \\
0.4572^{*}\end{array}$ & $0.4491^{*}$ & $0.4532^{*}$ & $0.4438^{*}$ & $0.4450^{*}$ & $0.4521^{*}$ & $0.4412^{*}$ & $0.4581^{*}$ \\
\hline Market Size & Population & $(0.0312)$ & $(0.0304)$ & $(0.0301)$ & $(0.0311)$ & $(0.0301)$ & $(0.0322)$ & $(0.0319)$ & $(0.0313)$ & $(0.0301)$ & $(0.0303)$ & $(0.0326)$ \\
\hline Economic & & $0.2121^{*}$ & $0.2142^{*}$ & $0.2043^{*}$ & $0.2055^{*}$ & $0.2182^{*}$ & $0.2144^{*}$ & $0.2113^{*}$ & $0.2032^{*}$ & $0.2091^{*}$ & $0.2052^{*}$ & $0.2088^{*}$ \\
\hline \multirow[t]{2}{*}{ Development } & In GDPPC & $(0.0211)$ & $(0.0217)$ & $(0.0221)$ & $(0.0223)$ & $(0.0218)$ & $(0.0209)$ & $(0.0214)$ & $(0.0218)$ & $(0.0201)$ & $(0.0204)$ & $(0.0206)$ \\
\hline & & $0.2213^{*}$ & $0.2134^{*}$ & $0.2139^{*}$ & $0.2122^{*}$ & $0.2071^{*}$ & $0.2031^{*}$ & $0.2221^{*}$ & $0.2051^{*}$ & $0.2009^{*}$ & $0.2004^{*}$ & $0.2311^{*}$ \\
\hline \multirow[t]{2}{*}{ Openness } & Trde $\%$ GDP & $(0.0231)$ & $(0.0221)$ & $(0.0251)$ & $(0.0224)$ & $(0.0219)$ & $(0.0213)$ & $(0.0242)$ & $(0.0291)$ & $(0.0233)$ & $(0.0249)$ & $(0.0218)$ \\
\hline & $\begin{array}{l}\text { Exchange } \\
\text { Rate }\end{array}$ & & $\begin{array}{l}0.0203^{*} \\
(0.0025)\end{array}$ & & & $\begin{array}{l}0.0209^{*} \\
(0.0041)\end{array}$ & $\begin{array}{l}0.0211^{*} \\
(0.0033)\end{array}$ & & $\begin{array}{l}0.0204^{*} \\
(0.0012)\end{array}$ & $\begin{array}{l}0.0201^{*} \\
(0.0045)\end{array}$ & $\begin{array}{l}0.0213 \alpha \\
(0.0024)\end{array}$ & $\begin{array}{l}0.0191 \\
(0.0013)\end{array}$ \\
\hline \multirow[t]{2}{*}{ Stability } & & & & $-1.24 \mathrm{E}-$ & 0.0001 & & & 0.0001 & & & & \\
\hline & Inflation & & & 06 & $(0.0021)$ & & & $(0.0021)$ & & & & \\
\hline \multirow[t]{2}{*}{ Human Capital } & Education & & & & $\begin{array}{l}0.1021 \varphi \\
(0.0412)\end{array}$ & $\begin{array}{l}0.0651 \\
(0.0481)\end{array}$ & $\begin{array}{l}0.0712 \\
(0.0423)\end{array}$ & $\begin{array}{l}0.0641 \\
(0.0411)\end{array}$ & $\begin{array}{l}0.0610 \\
(0.0464)\end{array}$ & $\begin{array}{l}0.0521 \\
(0.0418)\end{array}$ & $\begin{array}{l}0.0509 \\
(0.0411)\end{array}$ & $\begin{array}{l}0.0510 \\
(0.0416)\end{array}$ \\
\hline & & & & & & & $0.0429 \alpha$ & $0.0521^{*}$ & $0.0511 \alpha$ & $0.0418 \varphi$ & $0.0411 \alpha$ & $0.0405 \varphi$ \\
\hline \multirow[t]{6}{*}{ TRIMS } & TAs & & & & & & $(0.0135)$ & $(0.0137)$ & $(0.0121)$ & $(0.0127)$ & $(0.0122)$ & $(0.0109)$ \\
\hline & Trade Marks & & & & & & & & 05 & & & \\
\hline & Industrial & & & & & & & & & 0.0021 & & \\
\hline & Design & & & & & & & & & $(0.0001)$ & & \\
\hline & & & & & & & & & & & $0.0123^{*}$ & \\
\hline & Patents & & & & & & & & & & $(0.0042)$ & \\
\hline TRIPS & G \& P Index & & & & & & & & & & & $\begin{array}{l}0.0003 \\
(0.0102)\end{array}$ \\
\hline Wald Test & & & & & & & & & & & & \\
\hline Probability $>\mathrm{Chi}^{2}$ & & 0 & 0 & 0 & 0 & 0 & 0 & 0 & 0 & 0 & 0 & 0 \\
\hline Sargan Test & & & & & & & & & & & & \\
\hline Probability $>\mathrm{Chi}^{2}$ & & 1 & 1 & 1 & 1 & 1 & 1 & 1 & 1 & 1 & 1 & 1 \\
\hline
\end{tabular}

From the TSLS regression shows that large market size is always attract FDI. On average one percent increase in GDP per capita will increase foreign direct investment net inflows as percent of GDP 2.31percent. Similarly on average one percent increase in trade openness by minimizing tariffs and non-tariffs barriers will increase foreign direct investment net inflows as percent of GDP by 1.37percent. On the other hand on average of one percent increase in human capital will increase the foreign direct investment net inflow as percent of GDP by 1.24 percent. Macroeconomic stability also leads to flourishing FDI. In the TSLS regression shows that on average one percent increase in macroeconomic stability will increase foreign direct investment net inflows as percent of GDP 2.72 percent. On average one percent increase in 
agglomeration will increase foreign direct investment net inflows as percent of GDP 2.31percent. Strengthening infrastructure will increase the FDI. Here in the TSLS regression we see that on average one percent increase in infrastructure will increase the foreign direct investment net inflow as percent of GDP by 2.31 percent. On average one percent increase in financial development will increase the foreign direct investment net inflow as percent of GDP by 1.87 percent. Geographical location and language is also stimulating foreign direct investment. Protection of IPR in accordance with TRIPS and provisions of TRIMS is also increasing FDI for developing country.

Table 9. Determinate of foreign direct investment

\begin{tabular}{cllll}
\hline \multicolumn{5}{c}{ Dependent variables (FDI) } \\
\hline & \multicolumn{2}{l}{ OLS } & I & TSLS \\
\hline Market Size & I & $2.8451(1.4344)$ & $2.8451(1.4344)$ \\
Economic Development & $0.4241(0.2331)$ & $0.4241(0.2457)$ & $0.4238(0.0231)$ & $0.4238(0.0231)$ \\
Openness & $0.2119(0.0321)$ & $0.2119(0.0321)$ & $0.3244(0.0137)$ & $0.3244(0.0137)$ \\
Human Capital & $0.1120(0.0152)$ & $0.1120(0.0152)$ & $0.1347(0.0124)$ & $0.1347(0.0124)$ \\
& & & & \\
Macroeconomic Stability & $0.1891(0.0215)$ & $0.1891(0.0215)$ & $0.2170(0.0272)$ & $0.2170(0.0272)$ \\
Agglomeration & $0.1567(0.0237)$ & $0.1567(0.0237)$ & $0.2688(0.01829)$ & $0.2688(0.01829)$ \\
Infrastructure & $0.1577(0.0105)$ & $0.1577(0.0105)$ & $0.1956(0.0231)$ & $0.1956(0.0231)$ \\
Financial Development & $0.1942(0.0155)$ & $0.1942(0.0155)$ & $0.2541(0.0187)$ & $0.2541(0.0187)$ \\
Geographical Location & $0.0111(0.0129)$ & $0.0111(0.0129)$ & $0.0165(0.0154)$ & $0.0165(0.0154)$ \\
Language & $0.0089(0.0014)$ & $0.0089(0.0014)$ & $0.0096(0.0029)$ & $0.0096(0.0029)$ \\
TRIPS & $0.0281(0.0031)$ & $0.0281(0.0031)$ & $0.0292(0.0047)$ & $0.0292(0.0047)$ \\
TRIMS & $0.0106(0.0039)$ & $0.0106(0.0039)$ & $0.0178(0.0042)$ & $0.0178(0.0042)$ \\
Time Fixed Effect & YES & YES & YES & YES \\
Robust Standard Error & YES & YES & YES & YES \\
Clustered Standard Error & NO & YES & NO & YES \\
Observation & 1450 & 1450 & 1450 & 1450 \\
R $^{2}$ & 0.8123 & 0.8123 & 0.8562 & 0.8562 \\
\hline
\end{tabular}

\section{Conclusion}

The fundamental objectives of this paper is to determine the effects of TRIMS, TRIPS, WTO membership and trade liberalization on flowing of FDI in developing countries. The result demonstrate that by decelerating TRIMS related market distortion, consolidate and consistent framework of protection mechanism of the IPR with the light of TRIPS and unremitting trade liberalization procedure undoubtedly accelerate the flow of FDI in the developing country. Market size, economic advancement and agglomeration positively significant for flowing of 


\section{MlMacrothink}

International Journal of Accounting and Financial Reporting

ISSN 2162-3082

2018, Vol. 8, No. 1

FDI in developing country as well as human capital, infrastructure, macroeconomic stability also influence to flow of FDI in developing country. Strong financial development in the developing country can attract FDI inflow also. Finally geographical distance also makes a prime role for making investment decision in developing country.

Due to the transition of the business and economics multinational firms consider to make an investment by considering the multitudinous factors specifically the IPR protection and host countries institutional strength and macroeconomic stability. For ensuring the advancing economic phenomenon in the developing countries the host countries government inducing the MNC to construct investment with manifolds incentives. Robust transition of the behavior of host countries government and engaging the WTO membership helps the Developing country to recognize the affirmative avenue to reinforce and consolidate economic resilience with the substantial and rational policies and procedures.

\section{References}

Addison, T., \& Heshmati, A. (2003). The new global determinants of FDI flows to developing countries: The importance of ICT and democratization. WIDER Discussion paper 2003 (45): United Nations University.

Benhabib, J., \& Spiegel, M.M. (1994). The Role of Human Capital in Economic Development: Evidence from Aggregate Cross-Country Data. Journal of Monetary Economics, 34, 143-173.

Borenzstein, E., Gregorio, D., \& Lee, J.W. (1998). How Does Foreign Direct Investment Affect Economic Growth? Journal of International Economics, 45(1), 115-135.

Botric, V., \& Skuflic, L. (2006). Main determinants of foreign direct investment in the Southeast European countries. Transition Studies Review, 13(2), 359-77.

Cherunilam, F. (2007). International Business Text and cases $\left(4^{\text {th }}\right.$ ed.). Prentice-Hall of India Pvt. Ltd., New Delhi.

Claessens, Klingebiel, \& Schmukler. (2001). FDI and Stock market Development: Complement or Substitute.

Correa, C. (2000a). Intellectual Property Rights, the WTO and Developing Countries: The TRIPS Agreement and Policy Option. ZED-TWN, London.

Dawson, P.J. (2006). The export-income relationship and trade liberalization in Bangladesh. Journal of Policy Modeling, 28, 889-896.

El-Fergani, S.A. (2003). The Contribution of FDI Economic Development in Libya (in Arabic). Paper presented at the Symposium of Libyan Economy and to Spare the Oil Income, 23 June 2003, University of Al-Thadi.

Felbermayr, G., \& Kohler, W. (2007). Does WTO membership make a difference at the extensive margin of world trade, CESIFO Working Paper, 1898.

Fink, C., \& Braga, C.A.P. (1999). How stronger protection of intellectual property rights affects international trade flows. Working paper 2051, World Bank. 


\section{Macrothink}

International Journal of Accounting and Financial Reporting ISSN 2162-3082

Foad, H.S. (2005). Exchange Rate Volatility and Export Oriented FDI. A Paper from Emory University, Atlanta, GA, 2-7.

Galan, J.I., González- Benito, J., \& Zuñiga- Vincente, J.A. (2007). Factors determining the location decisions of Spanish MNEs: An analysis based on the investment development path. Journal of International Business Studies, 38(6), 975-97.

Greenaway, D., Sapsford, D., \& Praffenzeller, S. (2007). Foreign Direct Investment, Economic Performance and Trade Liberalizations. World Economy, 30(2), 197-210.

Hakura, D., \& Florence, J. (1999). The Role of Inter- and Intra-industry Trade in Technology Diffusion. IMF Working Paper 99/58, International Monetary Fund, Washington, DC.

Helleiner, G. (2002). Trade policy and industrialization in turbulent times. Routledge.

Javorcik, B.S. (2004). The composition of foreign direct investment and protection of intellectual property rights: Evidence from transition economies. European Economic Review, $48,39-62$.

Jordan, J.C. (2004). Foreign Direct Investment and Neighboring Influences. Unpublished doctoral thesis, University of Pretoria.

Kandiero, T., \& Chitiga, M. (2006). Trade openness and foreign direct investment in Africa. South African Journal of Economic and Management Sciences, 9(3), 355-70.

Kennedy, K.C. (2003). A WTO Agreement on Investment: A solution in search of a problem? 24 U. Pa. J. International Economics, 77.

Lee, J.Y., \& Manseld, E. (1996). Intellectual property protection and U.S. foreign direct investment. The Review of Economics and Statistics, 2, 181-186.

Lesser, W. (2002). The Effects of intellectual property rights on foreign direct investment and imports in developing countries. IP Strategy Today, 4, 1-16.

Li, H.Q. (2001). The Relation between Trade and Foreign Direct investment and The Implication for the WTO. Published Thesis, University of Toronto, Department of Law.

Li, Q., Vashchilko, A., \& Vashchilko, T. (2010). Interstate Political Relations and Bilateral FDI Flows. Paper prepared for presentation at the International Political Economy Society Meeting edn. Harvard University, Cambridge, Mass.

Lippoldt, D. (2006). Intellectual property rights, pharmaceuticals and foreign direct investment. Groupd'Economie Mondale de Sciences Po. Policy Brief 2006. Paris.

Luo, Y., \& Shenkar, O. (2006). The multinational corporation as a multilingual community: Language and organization in a global context. Journal of International Business Studies, 37, 321-339.

Maskus, K.E., \& Penubarti, M. (1995). How trade related are intellectual property rights? Journal of International Economics, 39(3), 227-248. 


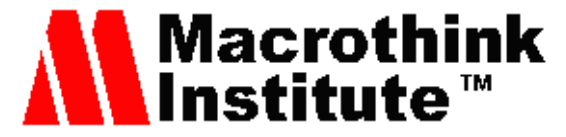

International Journal of Accounting and Financial Reporting

ISSN 2162-3082

2018, Vol. 8, No. 1

Mollick, A.V., Ramos-Duran, R., \& Silva-Ochoa, E. (2006). Infrastructure and FDI inflows into Mexico: A Panel Data approach. Global Economy Journal, 6(1).

Nishimizu, M., \& Page, J. (1991). Trade policy, market orientation and productivity change in industry. Trade theory and economic reform: Essays in honor of Bela Balassa. Cambridge, MA: Brasil Blackwell.

Onyeiwu, S., \& Shrestha, H. (2004). Determinants of foreign direct investment in Africa. Journal of Developing Societies, 20, 89-106.

Park, W.G., \& Lippoldt, D.C. (2007). Technology transfer and the economic implications of the strengthening of intellectual property rights in developing countries. OECD Trade Policy Working Paper 62.

Rapp, R.T., \& Rozek, R. (1990). Benefits and costs of intellectual property rights protection in developing countries. Journal of World Trade, 24(5), 75-102.

Razafimahefa, I., \& Hamori, S. (2005). An empirical analysis of FDI competitiveness in Sub-Saharan Africa and developing countries. Economics Bulletin, 6(20), 1-8.

Seyoum, B. (1996). The Impact of Intellectual Property Rights on Foreign Direct Investment. Columbia J. World Business, 31(1), 51-59.

Smarzynska Javorcik, B. (2004). The Composition of Foreign Direct Investment and Protection of Intellectual Property Rights: Evidence from Transition Economies. European Economic Review, 48(1), 39-62.

Smith, P. (1999). Are weak patent rights a barrier to U.S. exports? Journal of International Economics, 48(1), 151-177.

Tybout, J.R. (1992). Linking trade and productivity: New research directions. The World Bank Economic Review, 6, 189-211.

Wakasugi, R. (2007). Vertical intra-industry trade and economic integration in East Asia. Asian Economic Papers, 6(1), 26-39.

$\mathrm{Xu}$, B. (2000). Multinational Enterprises, Technology Diffusion and Host Country Productivity Growth. Journal of Development Economics, 62(2), 477-493.

Yang, G., \& Maskus, K.E. (2001). Intellectual property rights and licensing: An econometric investigation. Weltwirtschaftliches Archiv, 137(1), 58-79.

\section{Copyright Disclaimer}

Copyright for this article is retained by the author(s), with first publication rights granted to the journal.

This is an open-access article distributed under the terms and conditions of the Creative Commons Attribution license (http://creativecommons.org/licenses/by/4.0/) 